\title{
중간볼기근 강화 운동 시 하지 정렬이 엉덩관절 벌림근의 근활성도 및 근동원 순서에 미치는 영향
}

\author{
신승환, $\mathrm{AT}, \mathrm{MS}^{1}$, 신호진, $\mathrm{PT}, \mathrm{PhD}^{* 2}$, 조휘영, $\mathrm{PT}, \mathrm{PhD}^{* 2}$ \\ ${ }^{1}$ 고려대학교 스포츠의학전공, ${ }^{*}$ 가천대학교 물리치료학과
}

\begin{abstract}
Effect of Lower Extremity Alignment during Gluteus Medius
Strengthening Exercise on Hip Abductor Muscle Activity and Muscle Recruitment Pattern

Seung-Hwan Shin, AT, MS ${ }^{1}$, Ho-Jin Shin, PT, $\mathrm{PhD}^{* 2}$, Hwi-Young Cho, PT, PhD ${ }^{* 2}$

${ }^{1}$ Dept. of Sports Medicine, Korea University, Republic of Korea

${ }^{* 2}$ Dept. of Physical Therapy, Gachon University, Republic of Korea
\end{abstract}

Purpose The purpose of this study was to investigate the effects of alignment of the lower extremity during hip abduction exercise and clamshell exercise. Methods The subjects were twenty healthy men without low back pain or lower limb pain. Subjects performed four gluteus medius exercises: hip abduction $(A B)$, hip abduction with the alignment of the lower extremity (AB-AL), clamshell (CLAM), clamshell with the alignment of lower extremity (CLAM-AL). Surface EMG was used to measure hip abductor muscle activity and recruitment pattern from the five muscles: gluteus medius (Gmed), tensor fascia latae (TFL), gluteus maximus upper fiber (GmaxU), gluteus maximus lower fiber (GmaxL), and quadratus lumborum (QL). Results TFL EMG activity was significantly greater in AB than in AB-AL (p>.05). Gmed was significantly greater in CLAM than in CLAM-AL. Gmed, TFL, QL were significantly greater AB than CL. GmaxU, GmaxL were significantly greater CLAM than $\mathrm{AB}(\mathrm{p}>.05)$. In the recruitment pattern, there was a difference between $\mathrm{AB}$ and CLAM $(\mathrm{p}<.05)$. However, In both exercises, there was no difference according to lower extremity alignment $(\mathrm{p}<.05)$. Conclusion It is recommended to perform the exercise in consideration of the type of exercise and the alignment of the lower extremity according to the aim of training.

Key words Hip abduction, Clamshell, Gluteus medius, Muscle activity, Lower extremity alignment

Corresponding author Ho-Jin Shin (gpgkorea89@gmail.com), Hwi-young Cho (hwiyoung@gachon.ac.kr)

Received date

06 Oct 2021

Revised date

12 Oct 2021

Accept date

15 Oct 2021

\section{I. 서 론}

볼기근은 몸통과 척추 기능에 중요한 기여자로 여겨지며, 허 리통증 관리에 중요한 역할을 한다 ${ }^{1,2)}$. 그 중 중간볼기근은 해 부학적으로 이마면에서의 한발 서기 동안 반대쪽 골반 위치를 조절하여 엉덩관절과 골반의 가쪽 안정성에 큰 역할을 한다. ${ }^{3)}$ 또한 일상생활에서 기능적인 움직임, 신체 이동과 스포츠 활 동 등에서 빈번히 나타나는 한발 지지 자세의 안정성 확보를 위해 매우 중요하다. ${ }^{4,5,6)}$

중간볼기근의 근력 약화, 비정상적인 동원순서 등과 같은 기능부전은 계단오르기, 보행, 앉은상태에서 일어서기 등의 일 상생활의 활동에 어려움을 겪도록 하며, 엉덩관절의 조절능력 을 감소시켜 골반의 비대칭을 유발하고 하지의 정렬에 부정적

http:dx.doi.org/10.17817/2021.10.12.1111691
인 영향을 미친다. ${ }^{7,89)}$ 이는 하지 질환을 유발할 수 있고, 기 존 연구들에서 많은 하지 손상의 관련성을 보고하였다. ${ }^{10,11)}$ Fredericson 등(2000)은 중간볼기근의 약화에 의해 엉덩정강 근막띠 증후군이 발생할 수 있다고 보고하였고, ${ }^{8)}$ Hughes 등 (2006)은 착지 동작 시 볼기근의 약화로 인해 발생될 수 있는 과도한 밖굽이 무릎과 넙다리뼈의 회전은 앞십자인대의 잠재 적인 손상기전이라고 언급하였다. ${ }^{12)}$ 뿐만 아니라 허리통증, ${ }^{13}$ 급성 엉덩관절 통증 및 뼈관절염, ${ }^{14,15)}$ 발목염좌, ${ }^{16)}$ 엉덩정강근 막띠 증후군 ${ }^{17)}$ 은 중간볼기근의 약화가 주요한 원인이다. 이로 인해 중간볼기근의 근력 증가와 엉덩관절 벌림 시 올바른 근 동원순서의 달성은 재활에 있어 중요한 요소로 여겨졌다. ${ }^{18,19)}$

중간볼기근의 강화 훈련은 보상작용으로 발생될 수 있는 넙다리근막긴장근과 허리네모근의 과활성 및 잘못된 활성 패 턴을 개선시킬 수 있고, 하지의 병리적 문제의 개선을 가져온 다. ${ }^{80)}$ 따라서 중간볼기근의 기능부전 개선은 하지 근골격계 
질환의 재활에 있어 중요한 역할을 한다. 중간볼기근 기능을 개선시키기 위한 운동은 옆으로 누운 상태에서 엉덩관절 벌림 운동, 한 발 스쿼트, 한 발 데드리프트, 클램쉘 운동, 런지, 한 발 뛰기 등 다양한 운동이 있다. ${ }^{21)}$ 이러한 운동 중 열린사슬 운동으로 옆으로 누운 상태에서 엉덩관절 벌림 운동과 클램쉘 운동이 있고, 임상에서 체중부하가 더해지는 운동을 하기 어 려운 대상자에게 중간볼기근 강화와 근활성 재교육을 위해 사 용되어지고 있는 운동이다.

이와 같이 중간볼기근 훈련을 더 효과적으로 하기 위해 생 체 되먹임 장치와 골반벨트의 사용, 신체의 각도 변화와 움직 임의 변화가 중간볼기근의 근활성 변화에 미치는 영향에 대한 연구들이 기존에 보고되었다. ${ }^{22,23,24)}$ 하지만 신체의 정렬 유무 에 따라서 엉덩관절 벌림운동과 클램쉘 운동이 중간볼기근의 근활성과 근동원순서에 미치는 영향은 보고되지 않았다. 따라 서 본 연구는 중간볼기근 강화를 위한 운동 시 하지의 정렬이 엉덩관절 벌림근의 근활성도와 근동원순서에 미치는 영향을 알아보고자 한다.

\section{II. 연구 방법}

\section{1. 연구대상 및 연구기간}

본 연구는 인천에 위치한 $\mathrm{G}$ 대학교에서 진행되었다. 건강한 20 대 성인 남성 20 명을 대상으로 실시하였다. 대상자의 제외 기준은 다음과 같다. 1) 허리통증 또는 하지의 통증을 가지고 있는 자, 2) 최근 6 개월 이내에 허리통증 및 하지의 통증으로 인한 투약이나 물리치료를 받은 적이 있는 자, 3) 중추 또는 말초신경에 병변이 있는 자. 모든 대상자는 실험의 목적과 절
차 및 주의사항, 그리고 실험 시 수행하게 될 측정방법에 대 해 충분히 설명 받았다. 이후 실험 참가동의서에 동의를 받은 후 실험을 실시하였다.

\section{2. 연구방법 및 절차}

본 연구설계는 중재에 따른 단일집단 사전 사후 측정설계로 구성하였다. 모든 대상자들은 측정 전 선정된 근육에 근전도 를 부착하였다. 엉덩관절 벌림 운동과 클램쉘 운동을 수행하 였고, 두 운동 모두 비정렬상태와 정렬상태에서 수행하였다. 운동 중 중간볼기근, 넙다리근막긴장근, 큰볼기근 위쪽섬유, 큰볼기근 아래쪽섬유, 허리네모근의 근 활성도와 근 동원 순 서를 측정하기 위해 근전도 장비를 사용하였다.

\section{3. 운동 중재}

연구 대상자는 각 운동에 대해 충분한 설명을 듣고, 운동을 올바르게 수행할 때까지 연습을 진행하였다. 대상자들은 하지 비정렬 상태인 엉덩관절 벌림 운동과 클램쉘 운동, 하지 정렬 상태인 엉덩관절 벌림 운동과 클램쉘 운동을 무작위 순서로 실시하였다. 운동 시 골반의 중립 경사를 유지하도록 하였고, 골반의 보상적 움직임을 제어하고자 압력 바이오피드백을 매 트와 대상자의 허리사이에 위치시켜 $40 \mathrm{mmHg} \pm 5 \mathrm{mmHg}$ 을 유지하도록 하였다. ${ }^{18)}$ 각 동작은 3 회 반복하여 측정하였다.

\section{1 엉덩관절 벌림 운동}

대상자는 체간의 가쪽면에 압력 바이오 피드백을 위치시키고 옆으로 누운 자세를 취하도록 지시받았다. 바닥쪽 다리는 바닥 과의 안정성을 유지하기 위해 엉덩관절과 무릎관절을 굽힌 상

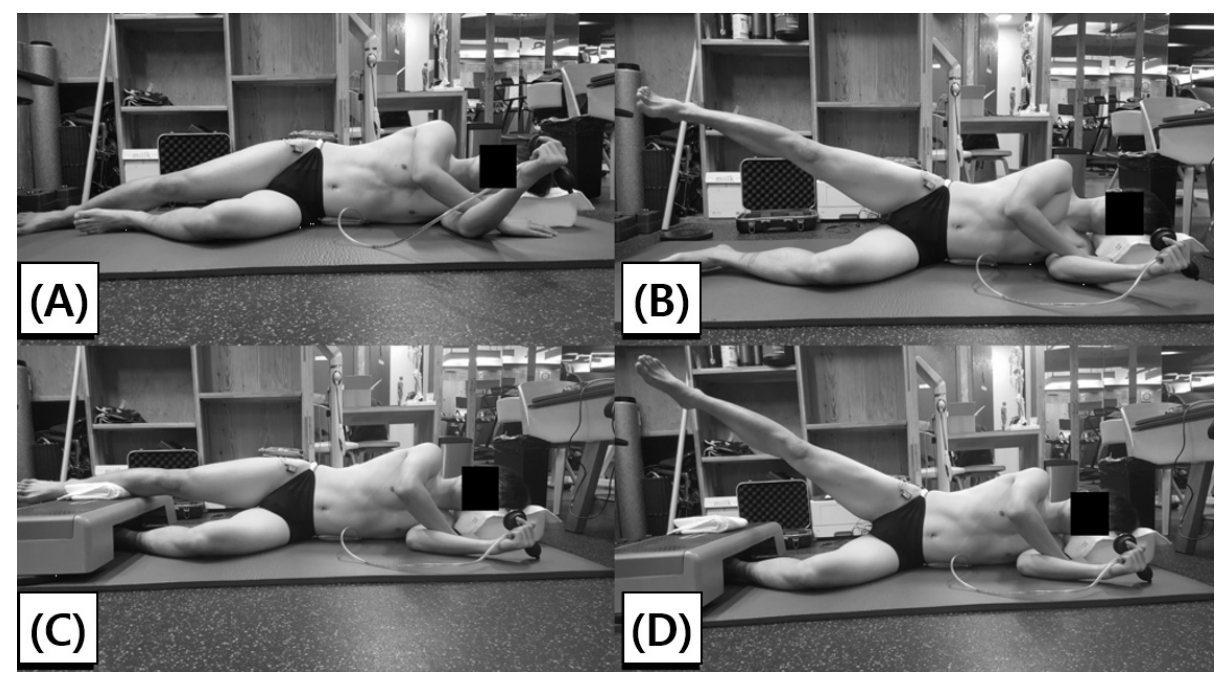

Figure 1. Hip abduction in side-lying

(A) Start position in hip abduction without alignment, (B) End position in hip abduction without alignment,

(C) Start position in hip abduction with alignment, (D) End position in hip abduction with alignment 


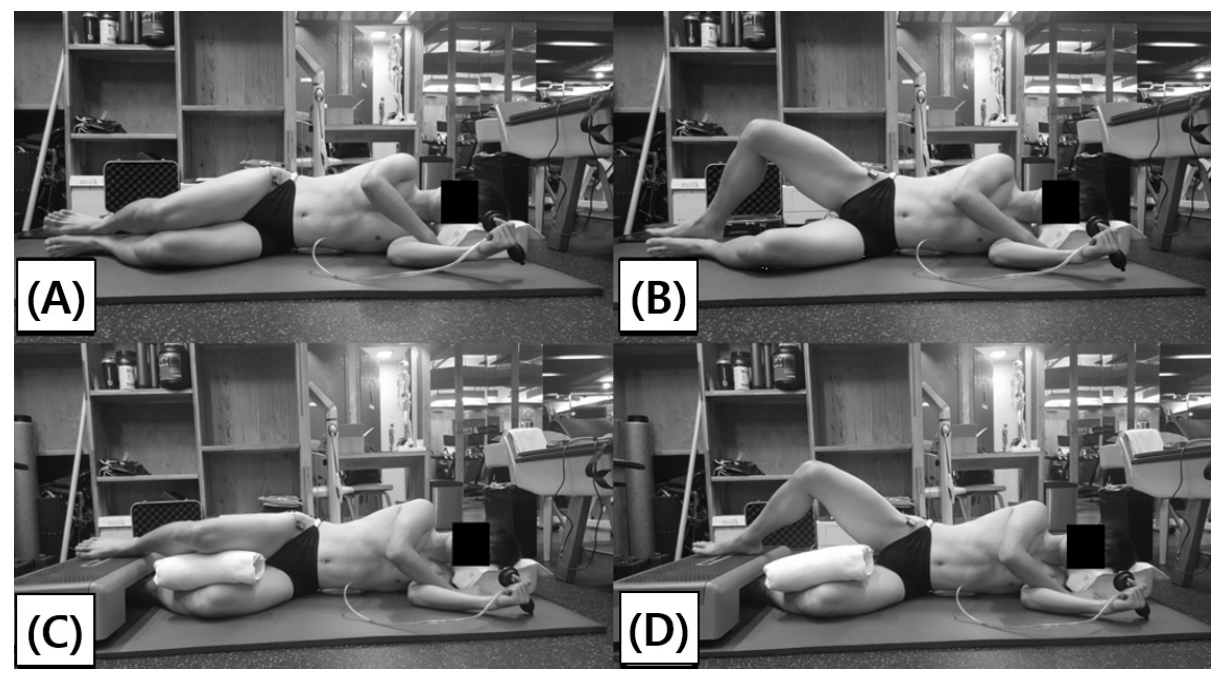

Figure 2. Clamshell exercise

(A) Start position in Clamshell without alignment, (B) End position in Clamshell without alignment,

(C) Start position in Clamshell with alignment, (D) End position in Clamshell with alignment

태로 두고, 천장쪽 다리는 엉덩관절과 무릎관절을 완전히 펴도 록 하였다. 자세를 갖춘 뒤 대상자는 엉덩관절을 벌림하도록 지시받았고, 이때 허리골반부위의 안정화를 위해 압력 바이오 피드백은 $40 \mathrm{mmHg} \pm 5 \mathrm{mmHg}$ 을 유지하도록 하였다. 정렬상태 의 엉덩관절 벌림 운동의 경우 추가적으로 하지의 수평 정렬 을 맞추기 위해 스텝박스와 수건을 이용하였다(Figure 1).

\section{2 클램쉘 운동}

대상자는 체간의 가쪽면에 압력 바이오 피드백을 위치시키고 옆으로 누운 자세를 취하도록 지시받았다. 다리는 엉덩관절 $30^{\circ}$, 무릎관절 $90^{\circ}$ 굽힘하도록 하였다. 자세를 갖춘 뒤 대상 자는 천장쪽 다리의 무릎이 바닥쪽 다리의 무릎과 최대한 멀 어지도록 벌림을 지시하였고, 이 때 양 발은 떨어지지 않도록 하였다. 이때 허리골반부위의 안정화를 위해 압력 바이오 피 드백은 $40 \mathrm{mmHg} \pm 5 \mathrm{mmHg}$ 을 유지하도록 하였다. 정렬상태의
클램쉘 운동의 경우 추가적으로 하지의 수평 정렬을 맞추기 위해 스텝박스와 수건을 이용하였다(Figure 2).

\section{4. 측정방법}

\section{1 근전도 측정}

중간볼기근 강화를 위한 운동 수행동안 근활성 및 근동원순서 를 측정하기 위해 무선 근전도(Telemyo DTS; Noraxon, USA)를 이용하였다. 무선 근전도를 통해 수집된 신호는 개인 용 컴퓨터의 MR3(ver.8.6) 소프트웨어를 이용하여 처리하였 다. 대상자의 선택된 근육 위 피부에 전극을 부착하기 전 정 확한 데이터를 얻기 위해 면도칼을 사용하여 체모를 제거하 고, 알코올 솜으로 소독한 뒤 전극을 부착하였다. 본 연구에 사용한 전극은 $\mathrm{Ag} / \mathrm{AgCl}$ 재질의 일회용 표면 전극을 사용하 였고, 부착 시 서로의 간격은 $20 \mathrm{~mm}$ 로 하였다. 전극 패드는 선행연구를 참고하여 중간볼기근(엉덩뼈능선 가장 높은 곳에

Table 1. Attachment of electromyography electrodes

\section{Muscle}

Gluteus medius

Tensor fascia latae

Gluteus maximus (upper fiber)

Gluteus maximus (lower fiber)

Quadratus lumborum

\section{Attachment region}

$2.5 \mathrm{~cm}$ below the highest point of the iliac crest

2 fingers wide in front of the greater trochanter of the femur

A point slightly above the midpoint of the imaginary line connecting the posterior superior iliac spine and the greater trochanter

Slightly below the midpoint of the imaginary line connecting the posterior superior iliac spine and the greater trochanter

$4 \mathrm{~cm}$ lateral from the transverse process of the spine at mid-level between the 12th rib and the iliac crest 
Table 2. Characteristics of participants

\begin{tabular}{cccccc}
$\mathrm{N}$ & Age (years) & Height $(\mathrm{cm})$ & Weight $(\mathrm{kg})$ & $\mathrm{BMI}\left(\mathrm{kg} / \mathrm{m}^{2}\right)$ \\
20 & $26.64 \pm 2.09$ & $175.28 \pm 3.72$ & $71.21 \pm 9.43$ & $23.07 \pm 2.58$ \\
\hline
\end{tabular}

서 $2.5 \mathrm{~cm}$ 아래쪽), 넙다리근막긴장근(넙다리뼈의 큰돌기 앞쪽 손가락 2개 너비 앞), 큰볼기근의 위쪽섬유(위뒤엉덩뼈가시와 큰돌기를 연결한 가상의 선의 중간지점 바깥쪽 약간 위 지점), 큰볼기근의 아래쪽섬유(위뒤엉덩뼈가시와 큰돌기를 연결한 가 상의 선의 중간지점 안쪽 약간 아래), 허리네모근( 12 번째 갈 비뼈와 엉덩뼈능선 사이 중간 높이에서 척추 가로돌기로부터 $4 \mathrm{~cm}$ 바깥쪽)에 부착하였다. ${ }^{19,20,21)}$

근전도 분석을 위해 표본추출률(sampling rate)은 $1,024 \mathrm{~Hz}$ 로 하였고, 대역 필터(band pass filter)를 20 350Hz로 설정 하였다. 데이터는 실제 측정의 앞 뒤 1 초를 제외한 중간 3 초 값을 사용하였고, 실효값(Root mean square, RMS)은 $100 \mathrm{~ms}$ 로 처리하여 분석하였다. 엉덩관절 벌림 운동과 클램 쉘 운동 동안 근동원순서의 측정 시 근육이 동원되는 시작의 기준은 휴식 시 근활성도 기본값(baseline)의 평균값에서 표 준편차 2 배로 설정하였다.

본 연구에서 측정된 각 근육의 근 활성도 측정값의 정규화 를 위해 최대수의적수축을 표준 도수 근력 검사에서 제시된 자세로 시행하였다. ${ }^{28)}$ 대상자들은 최대수의적수축을 3 회 반복 측정 하였고 각 시도 당 5 초간 유지하였다. 측정 시 시도 간 휴식시간은 1 분으로 설정하였다. 수집된 근전도 신호에서 오 차를 줄이기 위해 측정기간의 앞 뒤 1 초를 제외한 나머지 3 초 동안의 값의 평균을 데이터로 사용하였다.

\section{5. 통계 분석}

본 연구의 통계 분석은 SPSS 25.0 software (SPSS Inc, Illinois, USA)로 수행하였다. 모든 변수들에 대한 측정값은 3 회 반복 측정된 평균값과 표준편차로 산출하여 사용하였다. 원 자료는 샤피로 윌크 검정을 통해 정규성 검정을 시행하였 고, 하지 분절의 정렬 유무와 운동의 종류에 따른 근 활성도 차이를 알아보기 위해 이원 반복측정 분산분석을 사용하였다. 사후검정을 위해 대응표본 $\mathrm{t}$ 검정을 사용하였다. 운동 시 근육 간 동원 순서의 차이를 알아보기 위해 프리드만 검정을 사용 하였고, 사후검정을 위해 윌콕슨 부호 순위 검정을 사용하였 다. 통계적 유의수준은 0.05 로 설정하였다.

\section{III. 결 과}

\section{1. 연구대상자의 일반적 특성}

선정기준을 충족한 총 20 명의 대상자가 본 연구에 참여하였
다. 대상자의 일반적 특성은 Table 2 에 제시하였다. 본 연구 는 중간볼기근 강화 운동 시 하지의 정렬 유무가 중간볼기근, 넙다리근막긴장근, 큰볼기근 위쪽섬유, 큰볼기근 아래쪽섬유, 허리네모근의 근 활성도와 근 동원 순서에 미치는 영향을 알 아보기 위한 연구로 다음과 같은 결과를 얻었다.

\section{2. 근활성도 차이 비교}

본 연구 실험결과 모든 근육의 활성도에서 '운동X정렬'의 상호 교호작용이 없었다(P>.05). 사후분석 결과 하지분절의 수평 정렬 유무에 따라 엉덩관절 벌림 운동에서는 넙다리근막긴장 근(비정렬 상태: $22.67 \pm 9.88 \mathrm{mV}$, 정렬 상태: $20.64 \pm 8.48$ $\mathrm{mV})$ 에서 유의한 차이가 있었고 $(\mathrm{P}<.05)$, 클램쉘 운동에서는 중간볼기근(비정렬: $19.01 \pm 9.74 \mathrm{mV}$, 정렬: $17.15 \pm 9.57 \mathrm{mV}$ ) 에서 유의한 차이가 있었다 $(\mathrm{P}<.05)$. 비정렬 상태의 운동 간 비교(엉덩관절 벌림 운동 vs 클램셀)와 정렬 상태의 운동 간 비교 모두 중간볼기근, 넙다리근막긴장근, 큰볼기근 위쪽섬유, 큰볼기근 아래쪽섬유, 허리네모근에서 유의한 차이가 있었다 $(\mathrm{P}<.05)($ Table 3)(Figure 3).

\section{3. 근 동원 순서 비교}

본 연구 실험결과 각 운동의 근 동원 순서에 유의한 차이가 있었다. 비정렬 상태에서의 엉덩관절 벌림 운동 시 근 동원 순서는 넙다리근막긴장근 $(0.73 \pm 0.26 \mathrm{~s}), \quad$ 중간볼기근 $(0.82 \pm 0.36 \mathrm{~s})$, 큰볼기근 위쪽섬유 $(1.01 \pm 0.42 \mathrm{~s})$, 큰볼기근 아래쪽섬유(1.24 $\pm 0.66 \mathrm{~s})$, 허리네모근(1.62 $\pm 0.94 \mathrm{~s})$ 순서로 동원되었으며 $(\mathrm{P}<.05)$, 사후분석 결과 중간볼기근과 넙다리근 막긴장근의 비교를 제외한 나머지 근육 간 비교에서 유의한 차이가 있었다 $(\mathrm{P}<.05)($ Table 4)(Figure 4).

정렬 상태에서의 엉덩관절 벌림 운동 시 근 동원 순서는 넙다리근막긴장근 $(0.85 \pm 0.31 \mathrm{~s})$, 중간볼기근(0.85 \pm 0.29 $\mathrm{s})$, 큰볼기근 위쪽섬유 $(1.13 \pm 0.47 \mathrm{~s})$, 큰볼기근 아래쪽섬유 (1.28 $\pm 0.47 \mathrm{~s})$, 허리네모근(1.55 $\pm 0.69 \mathrm{~s})$ 순서로 동원되 었으며 $(\mathrm{P}<.05)$, 사후분석 결과 중간볼기근과 넙다리근막긴장 근의 비교를 제외한 나머지 근육 간 비교에서 유의한 차이가 있었다 $(\mathrm{P}<.05)$.

비정렬 상태에서의 클램쉘 운동 시 근 동원 순서는 중간볼 기근 $(0.70 \pm 0.22 \mathrm{~s})$, 큰볼기근 위쪽섬유 $(0.71 \pm 0.18 \mathrm{~s})$, 넙 다리근막긴장근 $(0.84 \pm 0.29 \mathrm{~s})$, 큰볼기근 아래쪽섬유 $(0.89$ $\pm 0.26 \mathrm{~s})$, 허리네모근(1.72 $\pm 0.65 \mathrm{~s})$ 순서로 동원되었으며 $(\mathrm{P}<.05)$, 사후분석 결과, 중간볼기근과 큰볼기근 위쪽섬유 간, 
Table 3. Comparison of muscle activity

\begin{tabular}{|c|c|c|c|c|c|c|}
\hline \multirow{2}{*}{$\begin{array}{l}\text { Millivolt } \\
\text { (mV) }\end{array}$} & \multicolumn{2}{|c|}{ AB exercise } & \multicolumn{2}{|c|}{ CLAM exercise } & \multirow{2}{*}{ Effect } & \multirow{2}{*}{ P-value } \\
\hline & pre & post & pre & Post & & \\
\hline Gmed & $25.43 \pm 6.79$ & $24.77 \pm 7.16$ & $19.01 \pm 9.74$ & $17.15 \pm 9.57$ & $\begin{array}{c}\text { Exercise } \\
\text { Alignment } \\
\text { E x A }\end{array}$ & $\begin{array}{c}0.002^{* * *} \\
0.118 \\
0.513\end{array}$ \\
\hline TFL & $22.67 \pm 9.88$ & $20.64 \pm 8.48$ & $6.61 \pm 6.24$ & $6.39 \pm 5.64$ & $\begin{array}{c}\text { Exercise } \\
\text { Alignment } \\
\text { E x A }\end{array}$ & $\begin{array}{c}<0.001^{\text {**** }} \\
0.035^{*} \\
0.068\end{array}$ \\
\hline GmaxU & $19.08 \pm 8.87$ & $19.98 \pm 9.85$ & $25.35 \pm 11.31$ & $27.1 \pm 11.65$ & $\begin{array}{c}\text { Exercise } \\
\text { Alignment } \\
\text { E x A }\end{array}$ & $\begin{array}{c}0.010^{*} \\
0.168 \\
0.656\end{array}$ \\
\hline GmaxL & $9.07 \pm 7.78$ & $8.44 \pm 5.02$ & $14.25 \pm 8.33$ & $15.6 \pm 7.24$ & $\begin{array}{c}\text { Exercise } \\
\text { Alignment } \\
\text { E x A }\end{array}$ & $\begin{array}{c}<0.001^{\text {***** }} \\
0.685 \\
0.193\end{array}$ \\
\hline QL & $19.78 \pm 7.32$ & $17.99 \pm 8.27$ & $6.16 \pm 2.61$ & $5.36 \pm 2.58$ & $\begin{array}{c}\text { Exercise } \\
\text { Alignment } \\
\text { E x A }\end{array}$ & $\begin{array}{c}<0.001^{\text {**** }} \\
0.139 \\
0.576\end{array}$ \\
\hline
\end{tabular}

Note. Values are expressed as mean \pm SD.

Abbreviation. ABD, side-lying hip abduction; CL, clam exercise; H-alignment, horizontal alignment of lower limb; Gmed, gluteus medius; TFL, tensor fascia latae; GmaxU, gluteus maximus upper fiber; GmaxL, gluteus maximus lower fiber; QL, quadratus lumborum.

*: $\mathrm{P}<.05,{ }^{* *}: \mathrm{P}<.01,{ }^{* * *}: \mathrm{P}<.001$
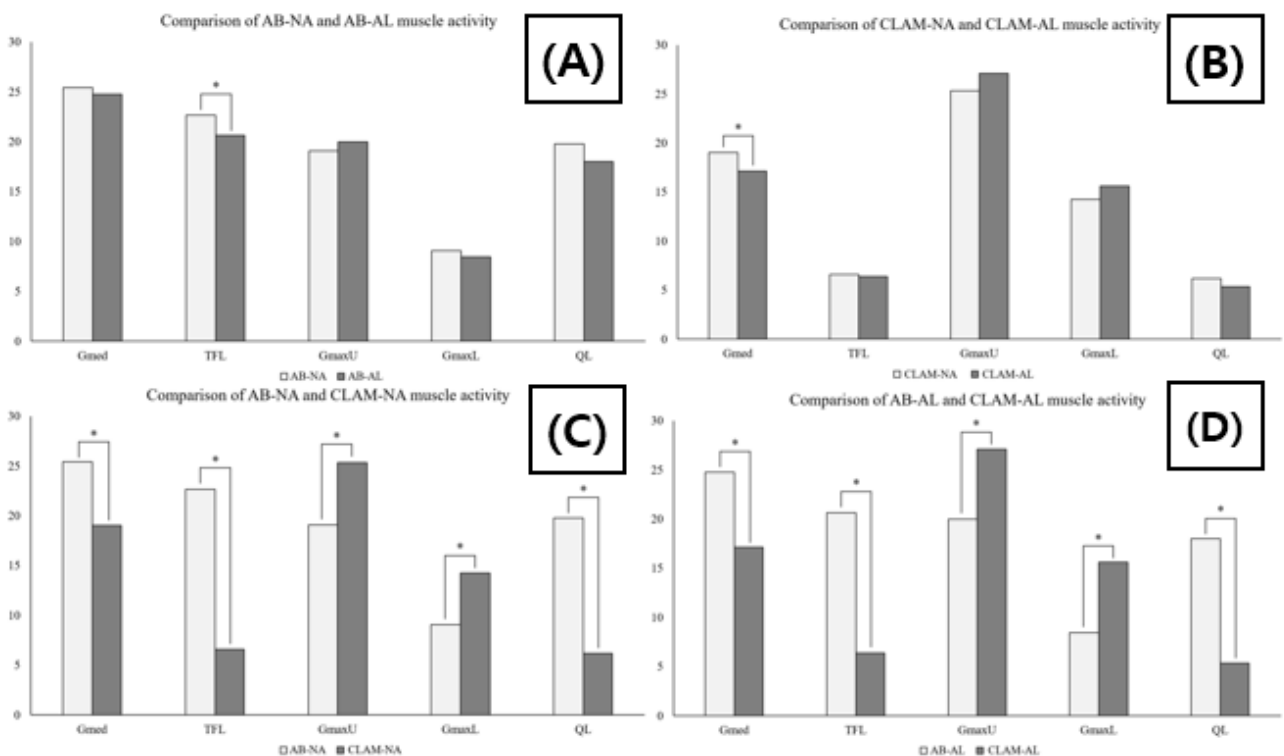

Figure 3. Comparison of muscle activity

(A) Between AB-NA condition and AB-AL condition, (B) Between CLAM-NA condition and CLAM-AL condition, (C) Between $A B-N A$ condition and CLAM-NA condition, (D) Between AB-AL condition and CLAM-AL condition, Abbreviation. $A B$, abduction; NA, non-alignment; AL, alignment, CLAM, clamshell.

넙다리근막긴장근과 큰볼기근 아래쪽섬유 간의 비교를 제외한 나머지 근육 간 비교에서 유의한 차이가 있었다 $(\mathrm{P}<.05)$.

정렬 상태에서의 클램쉘 운동 시 근 동원 순서는 중간볼기 근 $(0.78 \pm 0.35 \mathrm{~s})$, 큰볼기근 위쪽섬유 $(0.79 \pm 0.24 \mathrm{~s})$, 넙 다리근막긴장근 $(0.91 \pm 0.35 \mathrm{~s})$, 큰볼기근 아래쪽섬유 $(0.91 \pm$
$0.25 \mathrm{~s})$, 허리네모근(1.60 $\pm 0.59 \mathrm{~s})$ 순서로 동원되었으며 $(\mathrm{P}<.05)$, 사후분석 결과, 중간볼기근과 큰볼기근 위쪽섬유 간, 넙다리근막긴장근과 큰볼기근 아래쪽섬유 간의 비교를 제외한 나머지 근육 간 비교에서 유의한 차이가 있었다 $(\mathrm{P}<.05)$. 
Table 4. Comparison of muscle activity

\begin{tabular}{ccccccccl}
\hline \multicolumn{2}{c|}{ Condition } & Gmed & TFL & GmaxU & GmaxL & QL & p-value & Post hoc \\
AB & NA & $0.82 \pm 0.36$ & $0.73 \pm 0.26$ & $1.01 \pm 0.42$ & $1.24 \pm 0.66$ & $1.62 \pm 0.94$ & $<0.001^{* * *}$ & TFL $=$ Gmed $>$ GmaxU $>$ GmaxL $>$ QL \\
exercise & AL & $0.85 \pm 0.29$ & $0.85 \pm 0.31$ & $1.13 \pm 0.47$ & $1.28 \pm 0.47$ & $1.55 \pm 0.69$ & $<0.001^{* * * *}$ & TFL $=$ Gmed $>$ GmaxU $>$ GmaxL $>$ QL \\
CLAM & NA & $0.70 \pm 0.22$ & $0.84 \pm 0.29$ & $0.71 \pm 0.18$ & $0.89 \pm 0.26$ & $1.72 \pm 0.65$ & $<0.001^{* * *}$ & Gmed $=$ GmaxU $>$ TFL $=$ GmaxL $>$ QL \\
exercise & AL & $0.78 \pm 0.35$ & $0.91 \pm 0.35$ & $0.79 \pm 0.24$ & $0.91 \pm 0.25$ & $1.60 \pm 0.59$ & $<0.001^{* * *}$ & Gmed $=$ GmaxU $>$ TFL $=$ GmaxL $>$ QL \\
\hline
\end{tabular}

Note. Values are expressed as mean \pm SD.

Abbreviation. ABD, side-lying hip abduction; CL, clam exercise; Gmed, gluteus medius; TFL, tensor fascia latae; GmaxU, gluteus maximus upper fiber; GmaxL, gluteus maximus lower fiber; $Q L$, quadratus lumborum.

***: $P<.001$
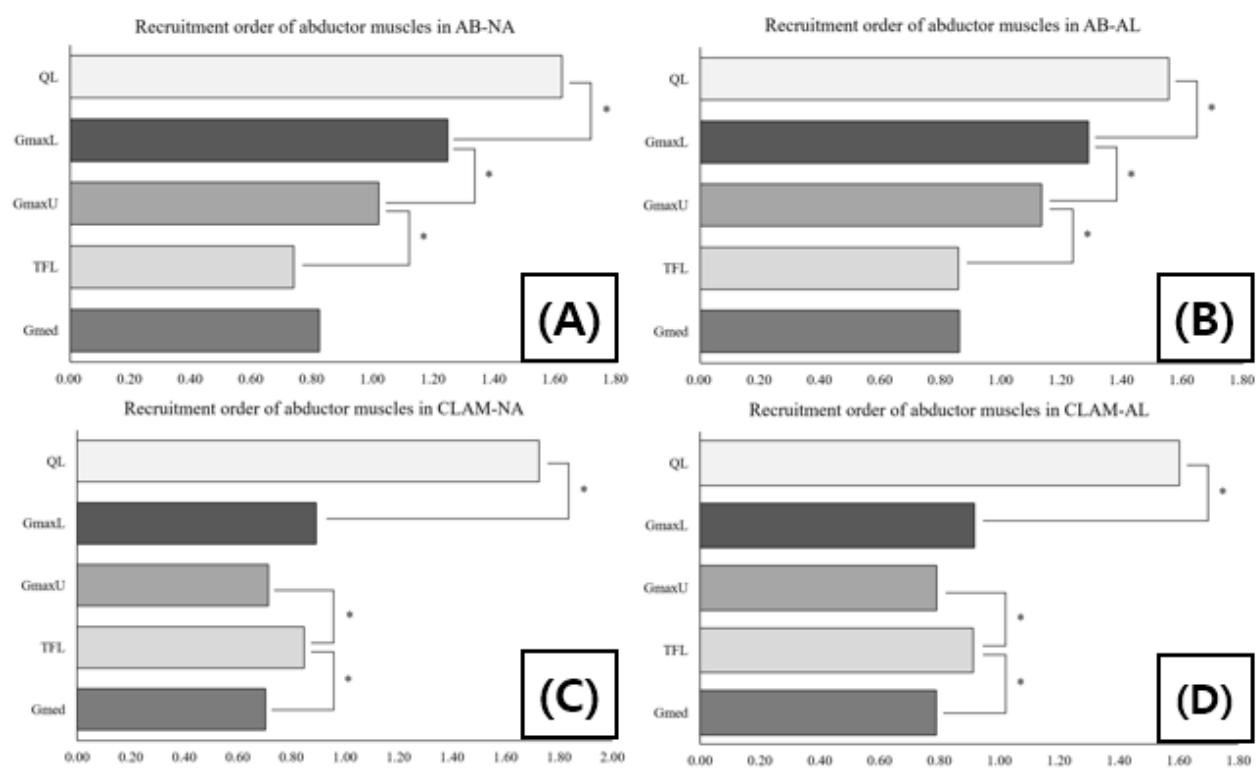

Figure 4. Recruitment pattern of abductor muscles

(A) Recruitment pattern in AB-NA condition, (B) Recruitment pattern in AB-AL condition, (C) Recruitment pattern in CLAM-NA condition, (D) Recruitment pattern in CLAM-AL condition, Abbreviation. AB, abduction; NA, non-alignment; AL, alignment, CLAM, clamshell.

\section{IV. 고 찰}

본 연구는 중간볼기근 강화 운동인 엉덩관절 벌림 운동과 클 램쉘 운동 시 신체의 정렬이 중간볼기근, 넙다리근막긴장근, 큰볼기근 위쪽섬유, 큰볼기근 아래쪽섬유, 허리네모근의 근활 성도와 근 동원 순서에 미치는 영향을 규명하고자 하였다.

연구 결과 엉덩관절 벌림 운동은 비정렬 상태가 정렬 상태 보다 넙다리근막긴장근의 활성도가 높은 것으로 나타났다. 엉 덩관절 벌림 운동과 관련된 다수의 선행연구에서 넙다리근막 긴장근의 활성도 감소를 위한 운동변형이 연구되어왔다. 주된 이유는 중간볼기근의 약화가 엉덩관절 벌림 시 작용하는 협력 근인 넙다리근막긴장근의 보상을 발생시키기 때문이다. ${ }^{16)}$ 이 러한 넙다리근막긴장근의 보상은 엉덩정강근막띠의 지속적인 긴장으로 이어져 무릎관절에 문제를 발생시킬 수 있다. ${ }^{8)}$ 엉덩
관절 벌림 운동 시 엉덩관절의 안·가쪽 돌림이 넙다리근막긴 장근의 활성에 미치는 영향에 대해 연구한 선행연구에서는 엉 덩관절의 중립상태가 가쪽돌림 상태보다 넙다리근막긴장근의 활성도가 낮게 나타났다. ${ }^{23)}$ 이와 함께 엉덩관절 안쪽돌림상태 에서 엉덩관절 벌림 운동 시 넙다리근막긴장근의 활성도 대비 중간볼기근의 활성도가 높은 것으로 나타났다. 이는 엉덩관절 벌림 운동형태 내에서의 변형 동작이 넙다리근막긴장근의 활 성도를 감소키고 중간볼기근의 활성도는 높일 수 있음을 보여 준다. 본 연구에서 비정렬 상태의 엉덩관절 벌림 운동이 정렬 상태보다 넙다리근막긴장근의 활성도가 높게 나타난 것은 선 행연구들의 기전과 마찬가지로 엉덩관절 벌림 운동이 정렬 상 태보다 엉덩관절 벌림에 대한 저항력을 많이 받는 자세에 의 한 것으로 사료된다. 나아가 근육의 길이 장력 관계의 관점에 서 보았을 때 엉덩관절 벌림 운동은 안정 시 길이보다 신장된 
상태에서 근수축이 발생되기 때문에 더 많은 신경근의 동원이 요구되었을 것으로 보인다. 이러한 결과는 엉덩정강근막띠의 긴장이 심한 환자의 경우 비정렬 상태의 엉덩관절 벌림 보다 정 렬 상태의 운동 적용이 더 좋은 결과를 보일 것으로 추측된다. 비정렬 상태의 클램셀 운동은 정렬 상태보다 중간볼기근의 활성도가 높은 것으로 나타났다. 이는 비정렬 상태의 클램쉘 운동이 정렬 상태보다 엉덩관절 벌림에 대한 저항력을 더 많 이 받는 자세이기 때문인 것으로 보인다. ${ }^{29)}$ 또한 정렬에 의한 근육의 길이 장력 변화에 의한 것으로도 사료된다. 이러한 결 과는 클램쉘 운동형태를 활용한 중간볼기근 강화가 목적일 경 우 비 정렬 상태의 클램쉘 운동이 정렬 상태의 클램쉘 운동보 다 더욱 효과적일 수 있다는 것을 보여준다.

클램쉘 운동은 엉덩관절 벌림 시 중간볼기근과 함께 작용 하는 넙다리근막긴장근의 활성도를 최소화하기 위한 대표적인 중간볼기근 강화 운동이다. ${ }^{23)}$ 안쪽돌림, 중립, 가쪽돌림 상태 의 엉덩관절 벌림 운동과 엉덩관절의 굽힘 각도 30 도, 45 도, 60 도 상태의 클램쉘 운동 시 중간볼기근과 넙다리근막긴장근 의 활성도를 비교한 선행연구에서는 각 상태에서 유의한 차이 가 없었고, 두 운동 간 비교에서 유의한 차이를 보고하였다. ${ }^{22)}$ 본 연구 결과 엉덩관절 벌림 운동과 클램쉘 운동간 차이는 중 간볼기근, 허리네모근, 넙다리근막긴장근은 엉덩관절 벌림 운 동형태에서 활성도가 높았고, 큰볼기근 위쪽섬유, 큰볼기근 아 래쪽섬유는 클램쉘 운동형태에서 높게 나타났다. 근 동원 순 서에서 엉덩관절 벌림 운동과 클램쉘 운동 간 차이는 있었지 만, 각 운동형태 내에서 정렬에 따른 유의한 차이는 나타나지 않았다. Janda 등(1996)에 의하면 엉덩관절 벌림 시 협력근 간의 근 동원 순서는 중간볼기근, 넙다리근막긴장근, 허리네모 근의 순서를 언급하였고, ${ }^{30)}$ Chaitow (2007)는 옆으로 누운 자세에서 엉덩관절 벌림 시 넙다리근막긴장근, 중간볼기근, 허 리네모근 순서로 동원되는 것을 이상적인 것으로 보고 있 다. ${ }^{19)}$ 선행연구에서 제시된 결과와 같이 각 동작에서의 정상 범위의 이상적인 근동원순서가 존재하며, 좋지 않은 일상생활 습관 혹은 질환으로 발생하는 부적절한 자세 정렬은 정상적인 근동원순서에서 벗어나 보상작용을 일으키기 때문에 중요한 변수로 여겨진다. ${ }^{31)}$ 본 연구에서 엉덩관절 벌림 운동의 근육 동원 순서는 넙다리근막긴장근과 중간볼기근, 큰볼기근 위쪽 섬유, 큰볼기근 아래쪽섬유, 허리네모근 순서로 동원되어 선행 연구들과 부분적으로 일치하였으며, 추가적으로 큰볼기근 위 쪽섬유와 아래쪽섬유의 벌림에 대한 기능 시 동원되는 순서를 알 수 있었다. 현재 클램쉘 운동 시 근 동원 순서에 대한 연 구는 보고되지 않았지만, 본 연구를 통해 클램쉘 운동 동안 근 동원 순서는 중간볼기근과 큰볼기근 위쪽섬유, 넙다리근막 긴장근과 큰볼기근 아래쪽섬유, 허리네모근 순으로 동원되는 것을 밝혀내었다.
하지만 본 연구에는 몇 가지 제한점이 있다. 첫째는 실험 의 대상자가 건강한 성인 남성으로 이루어져 일반화하기가 어 렵다. 둘째는 실험이 단일성으로 이루어져 본 연구에서 적용 된 운동의 장기적 이점을 알 수 없다. 셋째는 표면 근전도 자 체의 한계성이다. 향후 이러한 제한점들을 고려한 연구가 필 요할 것이다. 그럼에도 불구하고 연구의 결과는 중간볼기근의 약화 혹은 비정상적인 벌림근의 활성 패턴을 보이는 환자를 치료하는 물리치료사들에게 지식의 향상에 도움이 될 것으로 사료된다.

본 연구는 20 대 건강한 남성 20 명을 대상으로 엉덩관절 벌림 운동과 클램쉘 운동 시 신체 정렬이 중간볼기근, 넙다리 근막긴장근, 큰볼기근 위쪽섬유, 큰볼기근 아래쪽섬유, 허리네 모근의 근 활성도와 근 동원 순서에 영향을 미쳤다는 것을 규 명하였다. 따라서 훈련 목적에 따라 운동의 종류 혹은 동일한 운동에서 신체의 정렬 유무를 고려하여 운동을 수행하는 것을 추천한다.

\section{References}

1. Kankaanpaa M, Taimela S, Laaksonen D, et al. Back and hip extensor fatigability in chronic low back pain patients and controls. Archives of Physical Medicine and Rehabilitation. 1998;79:412-7.

2. Gombatto SP, Collins DR, Sahrmann SA, et al. Gender differences in pattern of hip and lumbopelvic rotation in people with low back pain. Clinical Biomechanics. 2006;21:263-71.

3. Grimaldi A. Assessing lateral stability of the hip and pelvis. Manual Therapy. 2011;16(1):26-32.

4. Hase K, Stein RB. Turning strategies during human walking. Journal of Neurophysiology. 1999;81:2914-22.

5. Leetun D, Ireland M, Wilison J. Core stability measures as risk factors for lower extremity injury in athletes. Medicine \& Science in Sports \& Exercise. 2004;36: 926-34.

6. Neumann DA. Kinesiology of the musculoskeletal system: Foundations for physical rehabilitation. St. Louis, Mosby; 2002.

7. Allison K, Bennell KL, Grimaldi A, et al. Single leg stance control in individuals with symptomatic gluteal tendinopathy. Gait \& Posture. 2016;49:108-13.

8. Fredericson M, Cookingham CL, Chaudhari AM, et al. Hip abductor weakness in distance runners with iliotibial band syndrome. Clinical Journal of Sport Medicine. 2000;10:169-75.

9. Earl J, Hertel J, Denegar C. Patterns of dynamic 
malalignment, muscle activation, joint motion and patellofemoral pain syndrome. Journal of Sport Rehabilitation. 2005;14:215-33.

10. Mascal CL, Landel R, Powers C. Management of patellofemoral pain targeting hip, pelvis, and trunk muscle function: 2 case reports. Journal of Orthopaedic \& Sports Physical Therapy. 2003;33:647-60.

11. Wilson E. Core stability: Assessment and functional strengthening of the hip abductors. Strength \& Conditioning Journal. 2005;27:21-3.

12. Hughes G, Watkins J. A risk-factor model for anterior cruciate ligament injury. Sports Medicine. 2006;36(5): 411-28.

13. Arab AM, Nourbakhsh MR. The relationship between hip abductor muscle strength and iliotibial band tightness in individuals with low back pain. Chiropractic \& Osteopathy. 2010;18:1.

14. Freeman S, Mascia A, McGill S. Arthrogenic neuromusculature inhibition: A foundational investigation of existence in the hip joint. Clinical Biomechanics (Bristol, Avon). 2013;28(2):171-7.

15. Rasch A, Byström AH, Dalen N, et al. Reduced muscle radiological density, cross-sectional area, and strength of major hip and knee muscles in 22 patients with hip osteoarthritis. Acta Orthopaedica. 2007;78(4):505-10.

16. Friel K, McLean N, Myers C, et al. Ipsilateral hip abductor weakness after inversion ankle sprain. Journal of Athletic Training. 2006;41:74-8.

17. Fredericson M, Cookingham CL, Chaudhari AM, et al. Hip abductor weakness in distance runners with iliotibial band syndrome. Clinical Journal of Sport Medicine. 2000;10(3):169-75.

18. Sidorkewicz N, Cambridge ED, McGill SM. Examining the effects of altering hip orientation on gluteus medius and tensor fascae latae interplay during common non-weight-bearing hip rehabilitation exercises. Clinical Biomechanics (Bristol, Avon). 2014;29(9):971-6.

19. Chaitow L. Positional Release Techniques E-Book. Elsevier health sciences; 2007.

20. Khayambashi K, Mohammadkhani Z, Ghaznavi K, et al. The effects of isolated hip abductor and external rotator muscle strengthening on pain, health status, and hip strength in females with patellofemoral pain: A randomized controlled trial. Journal of Orthopaedic \& Sports Physical Therapy. 2012;42(1):22-9.
21. Distefano LJ, Blackburn JT, Marshall SW, et al. Gluteal muscle activation during common therapeutic exercises. Journal of Orthopaedic \& Sports Physical Therapy. 2009;39(7):532-40.

22. Sidorkewicz N, Cambridge ED, McGill SM. Examining the effects of altering hip orientation on gluteus medius and tensor fascae latae interplay during common non-weight-bearing hip rehabilitation exercises. Clinical Biomechanics (Bristol, Avon). 2014;29(9):971-6.

23. Selkowitz DM, Beneck GJ, Powers CM. Which exercises target the gluteal muscles while minimizing activation of the tensor fascia lata? Electromyographic assessment using fine-wire electrodes. Journal of Orthopaedic \& Sports Physical Therapy. 2013;43(2):54-64

24. Cynn HS, Oh JS, Kwon OY, et al. Effects of lumbar stabilization using a pressure biofeedback unit on muscle activity and lateral pelvic tilt during hip abduction in sidelying. Archives of Physical Medicine and Rehabilitation. 2006;87(11):1454-8.

25. Lyons K, Perry J, Gronley JK, et al. Timing and relative intensity of hip extensor and abductor muscle action during level and stair ambulation: An EMG study. Physical Therapy. 1983;63:1597-605.

26. Arokoski MH, Arokoski Jari PA, Haara M, et al. Hip muscle strength and muscle cross sectional area in men with and without hip osteoarthritis. The Journal of Rheumatology. 2002;29(10):2185-95.

27. Cram JR, Kasman GS, Holtz J. Introduction to surface electromyography. Aspen; 1998.

28. Kendall FP, McCreary EK, Provance PG, et al MUSCLES: Testing and Function with posture and pain. 5th ed. Pennsylvania. Lippincott Williams \& Wilkins; 2005.

29. Lee JH, Cynn HS, Choi SA, et al. Effects of different hip rotations on gluteus medius and tensor fasciae latae muscle activity during isometric side-lying hip abduction. Journal of Sport Rehabilitation. 2013;22(4):301-7.

30. Janda V. Evaluation of muscle imbalance. In: Liebenson C, editor. Rehabilitation of the spine: A practitioner's manual. Baltimore: Williams and Wilkins; 1996.

31. Yang HS, Kim SM, Yoo EH, et al. Comparison of the difference with recruitment time and without patellofemoral pain syndrome patients. Journal of Orthopaedic \& Sports Physical Therapy. 2006;2(1):61-7. 